\title{
THE INFLUENCE OF HUSBAND'S ROLE ON MOTHER INTEREST IN GIVING EXCLUSIVE BREASTFEEDING
}

\author{
Yunik Windarti, Rizki Amalia \\ Faculty of Nursing and Midwifery, Universitas Nahdlatul Ulama Surabaya
}

\begin{abstract}
Background: Woman who become mother have gone through various life cycles, from pregnancy till childbirth. During this postpartum period, almost all mothers also breastfeed their babies. The process of restoring the body health after childbirth along with caring for the baby often leaves the mother physically and psychologically exhausted. So many mothers cannot provide exclusive breastfeeding. This is where the husband's role is very important to provide support to the mother. This study aimed to analyze the influence husband's role on the mother's interest in giving exclusive breastfeeding.

Subjects and Method: A cross-sectional study was conducted for 2 months on 46 postpartum mothers. This study conducted in Wonokromo, Surabaya, in 2020. The independent variable was the husband's role and the dependent variable was the mother's interest in giving exclusive breastfeeding. The data were collected using questionnaires and analyzed using Chi Square test.

Results: The results showed that out of 21 (57.14\%) mothers who had less husband's role, most had a low interest in giving exclusive breastfeeding. Of the 25 mothers who have a good husband's role, almost all (92\%) have a high interest in exclusive breastfeeding ( $\mathrm{p}<$ o.001), and it was statistically significant.

Conclusion: The better husband's role in supporting his wife, the higher the mother's interest in giving exclusive breastfeeding.
\end{abstract}

Keywords: husband role, mother, exclusive breastfeeding

\section{Correspondence:}

Yunik Windarti. Faculty of Nursing and Midwifery, Universitas Nahdlatul Ulama

Surabaya, East Java. Jl. Smea No 57 Surabaya, East Java. Email:

yunikwinda@unusa.ac.id. Mobile: 081330330090 